\title{
HATE SPEECH AND THE 2015 GENERAL ELECTIONS IN NIGERIA
}

\author{
Abiodun Fasakin ${ }^{1}$, Olusola Oyero ${ }^{2 \star}$, Kehinde Oyesomi, Nelson Okorie $^{4}$ \\ ${ }^{1} \mathrm{Mr}$, Covenant University, NIGERIA, aiminghigher0017@yahoo.com \\ ${ }^{2}$ Ass. Professor, Dr., Covenant University, NIGERIA, olusola.oyero@covenantuniversity.edu.ng \\ ${ }^{3} \mathrm{Dr}$, Covenant University, NIGERIA, kehinde.oyesomi@covenantuniversity.edu.ng \\ ${ }^{4} \mathrm{Dr}$, Covenant University, NIGERIA, nelson.okorie@covenantuniversity.edu.ng \\ ${ }^{*}$ Corresponding author
}

\begin{abstract}
Elections in the world are not taken with levity as it is one of the major determinants of what would become of the certain country in some years to come. During the 2015 general election in Nigeria, the political environment was intensified with the proliferation of adverts, political innuendos and propaganda messages. Media organisations in Nigeria, as always, became vehicles and channels of expressions and propaganda. A significant number of these messages had elements of hate speeches which were targeted at ridiculing opponents and opposition parties. Nigeria has witnessed several elections and campaigns with the intention of securing the people's vote, however, the political environment of Nigeria is not which that can be describe as conducive with candidates attacking personalities and political parties. Questions are being raised as citizens want to find out the role hate speeches plays in election campaigns and how it affects voter's choice of candidate with their perception about such candidate before, during and after the election. The essence of the hate speech is to ridicule and lower the esteem of others before well-meaning voters. This paper evaluated the extent at which hate speeches were used during the 2015 general elections in Nigeria. This paper was anchored on the social responsibility theory, which explains how media should ideally operate in a given society of social values and it is the standard against which the public judges. The paper concluded that many hate speeches were used across all the mass media during the 2015 general elections in Nigeria but as none of these people who uttered the hate speeches were not punished. The paper recommended that political actors that engage in the use of hate speeches during electioneering should be punished according to the electoral laws of the country. Furthermore, stringent punitive measures should be meted to media outlets that publish or broadcast hate speeches as a form of deterrent for the growth of democracy in Nigeria.
\end{abstract}

Keywords: Hate Speeches, Television, political campaign, elections and Nigeria

\section{INTRODUCTION}

Hate speech is any speech that attacks a person or group on the basis of attributes such as gender, ethnic origin, religion, race, disability, or sexual orientation (Dictionary.com, 2011). Hate speeches are utterances, 
typed documents, advertorials, musicals or any form of literature that are used to attack an individual, a group - religious, social, political, business - gender or race. In some countries, hate speech can fall under the law of sedition, incitement to violence, verbal abuse and the likes. Ezeibe (2015) supported that "Hate speech is any speech, gesture, conduct, writing or display which could incite people to violence or prejudicial action. Essentially, such speeches rob others of their dignity".

Jideofor Adibe (2014) as cited by Segun (2015) states, "Hate speech employs discriminatory epithets to insult and stigmatize others on the basis of their race, ethnicity, gender, sexual orientation or other forms of group membership. It is any speech, gesture, conduct, writing or display which could incite people to violence or prejudicial action. Segun (2015) added that "Hate speech is often the gateway to discrimination, harassment and violence as well as a precursor to serious harmful criminal acts. It is doubtful if there will be hate-motivated violent attacks on any group without hate speech and the hatred it purveys." The words of Segun have clearly shown that hate speech usually leads to violent attack on on any group or individual to which I is directed.

Election in any country of the world is not something that can be handled with levity. It determines how and where the country will head in terms of education, economy, infrastructure to mention but a few as this is the process of electing able and competent leaders to strive the ship of the nation for certain period of time. It is a vital tool that shapes the fate of any country. Nigeria is a country with different political, religious and ethnic diversities. This is one of the reasons elections in the country are always intense and always generating issues. Many elections have been conducted in the country and they are marred with one negative factor or the other - ranging from election irregularities, violence, hate speeches and the host of others.

The 2015 general elections in Nigeria, like other elections, have come and gone but the different events and issues surrounding the elections cannot be ignored by analysts, observers and scholars. The campaign period of the elections saw many hate speeches being used by politicians in the country. Most of these derogatory speeches and advertorials were used by the members of the two leading political parties in the country - People's Democratic Party (PDP) and All People's Congress (APC).

As the wave of the 2015 general elections drew nearer, political enthusiasts and politicians took to the media to promote their political parties and candidates. Supports were not just drawn for their choice of candidates or parties, but many abusive speeches were used against other parties and their candidates. During the campaign for the elections, there was serious war of words between the ruling party, People's Democratic Party (PDP) and the major opposition part, All People's Congress (APC). Most of the politicians were recorded on different television programmes attacking their political opponents. Advertisements, songs, rallies and documentaries were aired by television stations to attack and condemn the personality of people, their parties and ethnic backgrounds.

The media recorded numerous hate speeches being sent across them by the enthusiasts of these two political parties in the country. Segun (2015) noted that 'Hate and divisive speeches dominate political rallies as the elections heat up a political space already notorious for its violence. Voting will take place February 14 across the country. Hate and divisive speeches take on more frightening dimensions online via social media, notably Facebook, twitter and YouTube by cashing in on the fault-lines: religion and ethnicity'. Beyond doubt, the election was keenly contested and it was the first general election that will unseat an incumbent president in Nigeria.

There are certain laws in Nigeria that checkmate indiscriminate use of verbal and non-verbal attack on the personality of individuals or group of people. As this hate speeches are frequently used during election campaigns in Nigeria, one wonders whether it is lawful or illegal to use hate speeches during election campaign in the country. This paper seeks to evaluate the extent at which hate speeches were used during the 2015 general elections campaign in Nigeria.

\section{THEORETICAL FRAMEWORK: SOCIAL RESPONSIBILITY THEORY}

The theoretical bedrock of this study is the social responsibility theory. As a normative theory, social responsibility theory explains how media should ideally operate in a given society of social values and it is the standard against which the public judges. This theory asserts that media must remain free of government control, but in exchange media must serve the public .In performance this stewardship function through reportage of events and crisis situation the social responsibility theory emphasized that the media must keep with the professional standards of truth, objectivity, accuracy, and balance in order not to further aggravate the crisis situation but rather incorporate in reports diverse opinions, way forward to nail the crisis to it coffin for peace and progress to reign.

The theory emphasized that the mass media in their reports must not promote violence and civil disorder or 
be biased in favour of one minority group while relegating the views or accessibility of other minor or major groups to the background. The media as a whole should be pluralistic and reflect the diversity of their society, given access to various points of view and right to reply

The theory also posits that it is an ethical theory that an entity, be it an organization or individual, has an obligation to act to benefit society at large. In other for the broadcast media to act accordingly and also perform their social responsibilities to the society, the NBC was established to help regulate the broadcast media and also guide to performing their social responsibility function (Folarin, 1998). The underlying principle of the Social Responsibility Theory is that the press should be free to perform the functions which the Libertarian Theory had granted it freedom to perform; but that this freedom should be exercised with responsibility (Okunna and Omenugha 2012).

In relation to this study, it is apparent that the various mass media in the country have failed in their social responsibility to the society. The television was used to propagate various hate speeches during the 2015 general campaign in Nigeria. These hate speeches were either instigating the people against a political candidate or against a political, religious or ethnic group. A typical example is the speech made by the Katsina State governor, Ibrahim Shema. Shema was urging his supporters to reprise any provocation by the opposition and to kill them like they kill "cockroaches." The report was carried by Premium Times In October 2014. The various mass media in the country have over the years, turned to propaganda tools in the hands of politicians and powerful people in the country, rather than tools for nation building.

\section{LITERATURE REVIEW}

\section{Political Campaigns}

A political campaign is an organized effort which seeks to influence the decision making process within a specific group. In democracy, political campaigns often refer to electoral campaigns, where representatives are chosen or referendums are decided. In modern politics, the most high profile political campaigns are focused on candidates for head of state or head of government, often a President or Prime Minister (Boundless, 2016). Political campaigns are as old as civilization. As people became civilized, there was need to have a system that will run the affairs of the different societies we have in the word. Thus, political campaigns become necessities. It is a conscious effort of someone or individuals who seek the support of people or a group of people in order to win an elected post. Grace (2015) said that "In politics, campaigns have become an essential tool used amongst candidates contesting for various positions to get the electorates to vote for them".

When it is time for election and political campaign in any country, the atmosphere is always very intense. The political sector of the country will witness a heavy shake up and many activities and issues will come to the fore. A political campaign is step in the electoral process of any country and it ushers in the real voting process. The campaign usually determines how the real election will look like. Take for instance; the 2016 presidential election coming up in the United States of America on $8^{\text {th }}$ of November, 2016. The campaign for the real election has been ongoing for a while and many issues have been raised most especially about the two major contenders- Hilary Clinton and Donald Trump. Issues involving their - pasts, personal lives, and their relationship with people, accusations, hate speeches, and the host of others have been raised in the media and these issues may end up determining the result of the polls, come November 8.

Donald Trump in one of the campaign debates on Television was seen as describing his opponent Hillary Clinton as corrupt and would ensure Hillary faces a special investigative panel that would see her to jail if he becomes the president of the United States of America in the November election. Hillary on the other hand responded to Donald Trump by calling Trump a racist and a no respecter of women.

During the campaign, a candidate is expected to tell the electorate his mission and plan of actions if elected into the post. This is termed 'Manifestoes'. Each candidate seeks to influence and convince the people as the best person to occupy the vacant seat of power. But as noticed in many countries and Nigeria as a typical example, most of the candidates for election usually deviate from presenting their manifestoes to the people to delivering hate speeches against their opponents - personality, political parties, ethnic backgrounds and religions. These hate speeches have been pointed out as one of the causes of election violence in the country.

Many means can be adopted to deliver a political campaign - rallies, advertisements, interviews, posters, musicals, short dramas, souvenirs etc. Some of the politicians were seeing identifying themselves with the common men in the streets (something they would not have done when there was no election). The Channels Television News of October 26, 2016 reported that "Mrs. Aisha Buhari has also set out to play the 'Queen of Hearts' card to woo the ordinary man on the street. In Abuja, she was seen identifying with an 
akara (bean cake) seller who she helped to do some frying. The video and photo warmed it way to the heart of the internet, with comments on it including: 'Our next First Lady." The objective of the campaign methods is to generate support for a political candidate vying for a post.

A report by Daily Trust newspaper (March 21, 2015) on "2015: Inside Nigeria's most unusual political campaigns" reads - "Next Saturday's presidential election has been described as the most intense and expensive in Nigeria. It has also been seen as the most unusual, given the unprecedented violence heralding it despite peace accords"

\section{NIGERIA 2015 GENERAL ELECTIONS CAMPAIGNS: HATE SPEECHES AND THE ROLE OF TELEVISION}

Nigeria returned to civilian rule in 1999, after about 25years of military rule since her independence in 1960. The 2015 general elections made it the $5^{\text {th }}$ general elections to be conducted in the country from 1999. The election was keenly contested and it was one of the excruciating periods in the history of the country. What cannot be in doubt is the fact that the 2015 election was the most keenly contested since 1999 when Nigeria returned to civil rule. Going by historical precedent, the PDP had been expected to win easily. That it was not doing so going by projections before the election- that it was suddenly gasping for oxygen only weeks to the election got it thinking fast (Vanguard newspaper (Oct. 26, 2016),

Election campaigns in the country have always been uneasy and sometimes laced with violence and killings in the different parts of the country. The 2015 general elections witnessed series of hate speeches being used by politicians against their opponents. The election witnessed a huge speech attacks against individuals and groups. This was confirmed by a report by the Chairman of the National Human Rights Commission (NHRC), Prof. Chidi Odinkalu, which stated that the 2015 general election witnessed a rise in hate speeches during the campaign prior to the election.

Ukwueze and Uche (2015) also reported that, "Prior to the 2015 General Elections in Nigeria, many political watchers, local and international observers and of course the entire citizenry were concerned about the spate of hate speeches that characterized the political campaign messages and adverts of the two main political parties. As a result of this, there was palpable fear that the Nigeria state was on the edge of a precipice. This worrisome trend brought to the fore the suing for peace by both the local and international community. This culminated in the signing of a peace deal popularly referred to as the Abuja Peace Accord".

Also, Ayo-Aderele (2015) in a write-up published by Punch Newspapers on March 10, 2015, with the caption "When Hate Speeches Threaten an Election" decried the hate speeches that characterized political campaigns in Nigeria, from the uncouth, to the uncultured and absolutely damning statements emanating from both camps, Nigerians couldn't have heard anything worse in recent times as far as campaigns are concerned. He also added that "The personal attacks are not limited to sardonic jabs; the psychological war has been deployed in media advertisements, social media spaces and, in extreme cases, inter-personal discussions"

Hate speech involves attacks on a person or group on the basis of attributes such as gender, ethnic origin, religion, race, disability, or sexual orientation. In law, hate speech is any speech, gesture or conduct, writing, or display which is forbidden because it may incite violence or prejudicial action against or by a protected individual or group, or because it disparages or intimidates a protected individual or group (Ukwueze and Uche, 2015). Hate speeches are speeches that ridicules or attack an individual or a group of people. In the law of some countries, hate speech is speech, gesture or conduct, writing, or display which is forbidden because it incites violence or prejudicial action against or by a protected individual or group, or because it disparages or intimidates a protected individual or group. The law may identify a protected group by certain characteristics (Nockleby, 2000).

Television has a mass medium has the greatest credibility among the mass media due to its ability to transmit motion pictures as well as audio messages. It has been describes as the medium with the greatest effect on the audience because the information from it can be seen and heard. The television media in the country played a huge role in the propagation of hate speeches during the 2015 general elections campaigns in the country. Politicians, knowing the powerful effect of the medium, used various television channels to attack their opponents and other political parties.

During the campaign, many political enthusiasts and politicians were seen on the different television programmes attacking their political opponents with derogatory speeches during political rallies and even interviews. Television documentaries, political jingles and used by politicians to attack and condemn their political opponents. Notable ones were the documentary aired on African Independent Television (AIT) on March $1^{\text {st, }} 2015$ to condemn the persons of Asiwaju Bola Ahmed Tinubu ( APC Chieftain) and the APC 
presidential candidate, General Muhammad Buhari (Now president). This documentary made the Nigerian Broadcasting Commission to indict and sanction the two television stations alongside 21 other broadcast stations for violation of its code (Nigerianeye, October 28, 2016).

The mass media have many social responsibilities they are to perform in the society. They are to be used as tool for nation building and shun any news, information or report that will elicit violence or any bad behaviour in the society. Many television stations in Nigeria failed to live up to their social responsibility in the country as they were used as propaganda tools during the campaign for the 2015 general elections.

\section{INSTANCES OF HATE SPEECHES DURING 2015 GENERAL ELECTIONS CAMPAIGN IN NIGERIA}

A report by the Nigerian civil society in 2015 cited some of the hate speeches used during the 2015 general elections campaign in its report titled 'Hate speech, Issue based Campaigns and the 2015 General Elections'

- Katsina State Gov. Shema reportedly urged his supporters to attack opponents and referred to his political opponents as cockroaches urging his supporters to kill them as they kill cockroaches.

- The Ekiti State Governor, Peter Ayodele Fayose in January repeatedly took out front page newspaper advertorials warning voters not to vote for the APC presidential candidate Muhamadu Buhari. These adverts, now widely known as "death wish advertorials" insinuated that the presidential candidate was likely to die in office if elected, like the late President, Yaradua.

- Speaking during the PDP women presidential campaign rally in Kogi State, the Nation's First Lady, reportedly described Gen. Buhari as unfit to be the country's president, calling him old and braindead.

- Nigerian First Lady, Patience Jonathan is also recorded has having urged the members of the People's Democratic Party (PDP) to stone anyone that promises them change. "Change" is the slogan of the All Progressives Congress(APC).In the same campaign speech given at a rally which held on Monday, March 2, in Calabar, the capital of Cross River state, Mrs Jonathan is quoted as saying "Our people no dey born shildren wey dem no dey fit count. Our men no dey born shildren throway for street. We no dey like the people for that side." Thus making a derogatory statement obviously referring to the Northern parts of the country where the awful practice of child abandonment known as 'Almajiri' still occurs.

- After emerging unscathed after the plethora of criticism that followed the documentary on General Muhammadu Buhari, presidential candidate of the APC earlier in the year, A popular television Network, AIT, on March 1st aired a documentary titled 'Lion of Bourdillon'. The hour-long documentary, aired at 11 p.m. showcased various properties and companies across Lagos purportedly owned by Asiwaju Bola Ahmed Tinubu, a top leader of the APC describing him as "Nigeria's biggest landlord". It also alleged that the APC chieftain was "charged for narcotics" in 1993.

- Oba Akiolu of Lagos on April $3^{\text {rd }}, 2015$ said, 'On Saturday, if anyone of you, I swear in the name of God, goes against my wish that Ambode will be the next governor of Lagos state, the person is going to die inside this water...For the Igbos and others in Lagos, they should go where the Oba of Lagos heads to'

- Alhaji Mujahid Dokubo-Asari said, '2015 is more than do-or-die. You are a man and I am a man, we are going to meet at the battlefield' (News Express 3rd May, 2014)

- Mujahid Dokubo-Asari on Channels Television also said that General Muhammadu Buhari of the APC is a beast clothed in human skin and would ensure he does all in his power to make sure he does not become president of the Federal Republic of Nigeria.

\section{CONCLUSION}

Political campaigns by their nature, involve canvassing for votes in any modern society. Political communication as a tool involve a persuasive and strategic plan designed not only to provide consumers (voters) with information about the product( the politicians and/or the political party), but also to ensure that the target consumers are persuaded to be favourably disposed towards the product in order that the desired action will follow. The paper concludes that hate speeches were indiscriminately used during the 2015 general elections campaign in Nigeria. The speeches were uttered and propagated by both the print and broadcast media. Hate speeches should not be elements of political messages during electioneering. This is 
because hate speeches negate the fundamental principles of democracy in any modern society. It is therefore suggested that political actors that engage in the use of hate speeches during electioneering should be punished according to the electoral laws of the country. Furthermore, stringent punitive measures should be meted to media outlets that publish or broadcast hate speeches as a form of deterrent for the growth of democracy in Nigeria.

\section{ACKNOWLEDGEMENT}

This study is sponsored by the Covenant University Centre for Research, Innovation and Development (CUCRID), Covenant University, Ota- Nigeria.

\section{REFERENCE LIST}

Adibe, J. (2015). Fayose's advert: Offensive or hate speech? Adapted from a paper presented at a roundtable on hate speech organized by the Kukah Centre: Abuja, on 27 January. 2017.

Adie, V. O. \& Abbas, J. (2015). Inside Nigeria's most unusual political campaigns. Retrieved from: http://www.dailytrust.com.ng//weekly/index.php/politics/19352- on 15th February, 2017.

Ayo-Aderele, S. (2015). When Hate Speeches Threaten an Election. Retrieved from http://www.punchng. com/democracy-focus/when-hate-speeches-threaten-an-election/ on 4th February, 2017.

Boundless, (2016). The Modern Politcal Campaign: Retrieved from https://www.boundless.com/politicalscience/textbooks/boundless-political-science-textbook/campaigns-and-elections-8/the-modernpolitical-campaign-61/the-modern-political-campaign-345-5701/ on $7^{\text {th }}$ March, 2017

Ezeibe C. (2015) Hate speech and Electoral Violence in Nigeria: A paper submitted to the Department of Political Science University of Nigeria Nsukka

Folarin, B. (1998). Theories of Mass Communication, An introductory text. Ibadan: Stirling-Horden Publishers.

Grace, I. (2015). Political Advert Campaigns and Voting Behaviour: A Study of Akinwunmi Ambode's Election Ad Campaigns in Lagos State. A paper submitted to the Mass Communication Department, National Open University of Nigeria (NOUN), Lagos state, Nigeria.

Nigerian civil society, (2015). Hate speech, Issue based Campaigns and the 2015 General Elections. 2, 1119.

Nigerian Observer, (2015). Checking Hate Speech among Nigerian Politicians. Retrieved from http://www.nigerianobservernews.com/2015/02/checking-hate-speech-among-nigerian-politicians/ on 19th January, 2017.

Nigerianeye, (2016). NBC Indicts AIT and NTA for Documentary on Buhari. Retrieved from www.nigerianeye.com/2015/03/nbc-indicts-nta-ait-for-documentary-on-buhari on 8th February, 2017.

Nockleby, T. (2000), "Hate Speech," in Encyclopedia of the American Constitution, ed. Leonard W. Levy and Kenneth L. Karst, vol. 3. (2nd ed.), Detroit: Macmillan Reference US, pp. 1277-1279. Cited in "Library 2.0 and the Problem of Hate Speech," by Margaret Brown-Sica and Jeffrey Beall, Electronic Journal of Academic and Special Librarianship, vol. 9 no. 2 (Summer 2008).

Okunna, C. S. \& Omenugha, A. (2012). Introduction to Mass Communication (3rd Ed.). Enugu: New Generation Books.

Segun, O. (2015). Nigerian 2015 elections and the Internet of hate. Retrieved from http://itedgenews.com/2015/01/20/nigerian-2015-elections-and-the-internet-of-hate/ on 7th March, 2017.

Ukwueze, C.I., \& Uche, A. (2015). The Rise of Hate and Peace Journalism In The Nigerian Democratization Process: The Place of the New Media. Communication Panorama African and Global Perspective. Volume 1 Number 1 Sept-Oct 2015 Maiden Issue.

Vanguard newspaper, (Oct. 26, 2016). Nigerian politics and the 2015 election campaigns by Rotimi fasan. Retrieved from http://www.vanguardngr.com/2015/04/nigerian-politics-and-the-2015-electioncampaigns/ on 7th March, 2017. 